\title{
Disequilibrium of uranium mineralization - a case study of Devri area, Surajpur district, Chhattisgarh, India
}

\author{
Dheeraj Singh $^{1, *}$, U. P. Sharma ${ }^{2}$ and G. B. Rout ${ }^{3}$ \\ ${ }^{1}$ Atomic Minerals Directorate for Exploration and Research, Central Region, Civil Lines, Nagpur 440 001, India \\ ${ }^{2}$ Atomic Minerals Directorate for Exploration and Research, North Eastern Region, Nongmynsong, Shillong 793 001, India \\ ${ }^{3}$ Atomic Minerals Directorate for Exploration and Research, Begumpet, Hyderabad 500016 , India
}

Disequilibrium in the uranium series is a vital parameter to ascertain the state of equilibrium between uranium group (parent uranium) and its daughters, i.e. radium group of elements. The ${ }^{238} U$ isotope of uranium is the parent of $\mathbf{1 4}$ daughter isotopes forming the uranium series. The first five isotopes of ${ }^{238} \mathrm{U}$ series, i.e. ${ }^{238} \mathrm{U},{ }^{234} \mathrm{Th},{ }^{234} \mathrm{~Pa},{ }^{234} \mathrm{U}$ and ${ }^{230} \mathrm{Th}$ form uranium group and the sixth to last isotopes of ${ }^{238} \mathrm{U}$ series, i.e. ${ }^{226} \mathrm{Ra},{ }^{222} \mathrm{Rn},{ }^{218} \mathrm{Po},{ }^{214} \mathrm{~Pb},{ }^{214} \mathrm{Bi},{ }^{214} \mathrm{Po},{ }^{210} \mathrm{~Pb},{ }^{210} \mathrm{Bi},{ }^{210} \mathrm{Po}$ and ${ }^{206} \mathrm{~Pb}$ form radium group. Isotopes in the uranium and radium group usually remain in equilibrium within the group, but disequilibrium commonly exists between the two groups. In an open system, the mobility of radium is significant due to radon gas produced as a daughter element in the radium series. Anomalies with excess radium are commonly found around springs and seepages, whereas uranium anomalies are usually found under reducing environments. A study was carried out in Devri area, Surajpur district, Chhattisgarh, India, to decipher the state of disequilibrium in the area by analysing the drill core samples $(n=4470)$ from 43 boreholes. This study has revealed a strong disequilibrium $(65 \%)$ in favour of the parent uranium. This disequilibrium is due to cycles of dissolution and deposition of parent uranium; aided by the movement of groundwater and diverse geochemical behaviour of different radionuclides. In addition, loss of radon from the system might have also contributed to the disequilibrium in favour of the parent uranium. Linear regression coefficient between $\mathrm{U}_{3} \mathrm{O}_{8}$ (parent uranium) and $\operatorname{RaEq} .\left(\mathrm{U}_{3} \mathrm{O}_{8}\right)$ was calculated to be 0.82 . Strong disequilibrium in favour of the parent uranium will enhance the uranium ore reserve in Devri area.

Keywords: Beta-gamma method, disequilibrium factor, linear regression coefficient, radium group, uranium mineralization.

NUCLEAR power is a sustainable source of energy in which uranium is used as a fuel. In India, the Atomic Minerals Directorate for Exploration and Research is carrying out extensive uranium exploration programmes

\footnotetext{
*For correspondence. (e-mail: dsss.amd@gmail.com)
}

in different parts of the country. To quantify the total tonnage of uranium reserves in a natural repository, the state of disequilibrium in uranium ore must be known to avoid poor estimation of uranium reserves ${ }^{1,2}$. In the uranium series, equilibrium is achieved when the rate of formation of each member is equal to the rate of its decay. Two primary processes which are responsible for disequilibrium are migration of uranium to its present location in a time less than that required by its daughter products to reach approximate equilibrium and preferentially greater leaching of daughter products than of uranium $^{3}$. The importance of these aspects is being evaluated in uranium mineralization in Devri area, Surajpur district, Chhattisgarh, India. A study of the uranium series disequilibrium of drill core samples of Devri area has been done using gamma ray spectrometry and betagamma method of uranium estimation.

\section{Geology and uranium mineralization in the study area}

Devri area is located $10.50 \mathrm{~km}$, NNE of Jajawal uranium deposit (Figure 1). The Precambrian rocks in the DevriPakni-Dumhath area consist of a wide variety of metasomatic rocks, para- as well as ortho-metabasic rocks, and younger acidic and basic rocks. The older metasedimentary rocks are represented by quartzites, schists, calc-silicate rocks and amphibolites, which have been co-folded, migmatized and granitized. Trend of shear zone varies from E-W to NNE-SSW and is marked by intensely sheared, brecciated, silicified and mylonitized rocks of granites and gneisses. Dumhath-Chui and Godkatava streams represents a fault zone, and flow through a highly crushed and pulverized zone with general trend of $\mathrm{N} 70^{\circ} \mathrm{E}-\mathrm{S} 70^{\circ} \mathrm{W}$. Ferruginous quartzites, quartz-micaschist, granite-cataclasites, granite-gneisses and pegmatites are exposed in the southern part of the exploration block. Granite-gneisses/migmatite, containing pink feldspar with some xenoliths of meta-sediments and metabasics are exposed in the northern side of explored area ${ }^{4}$. Uranium mineralization intercepted in boreholes is 


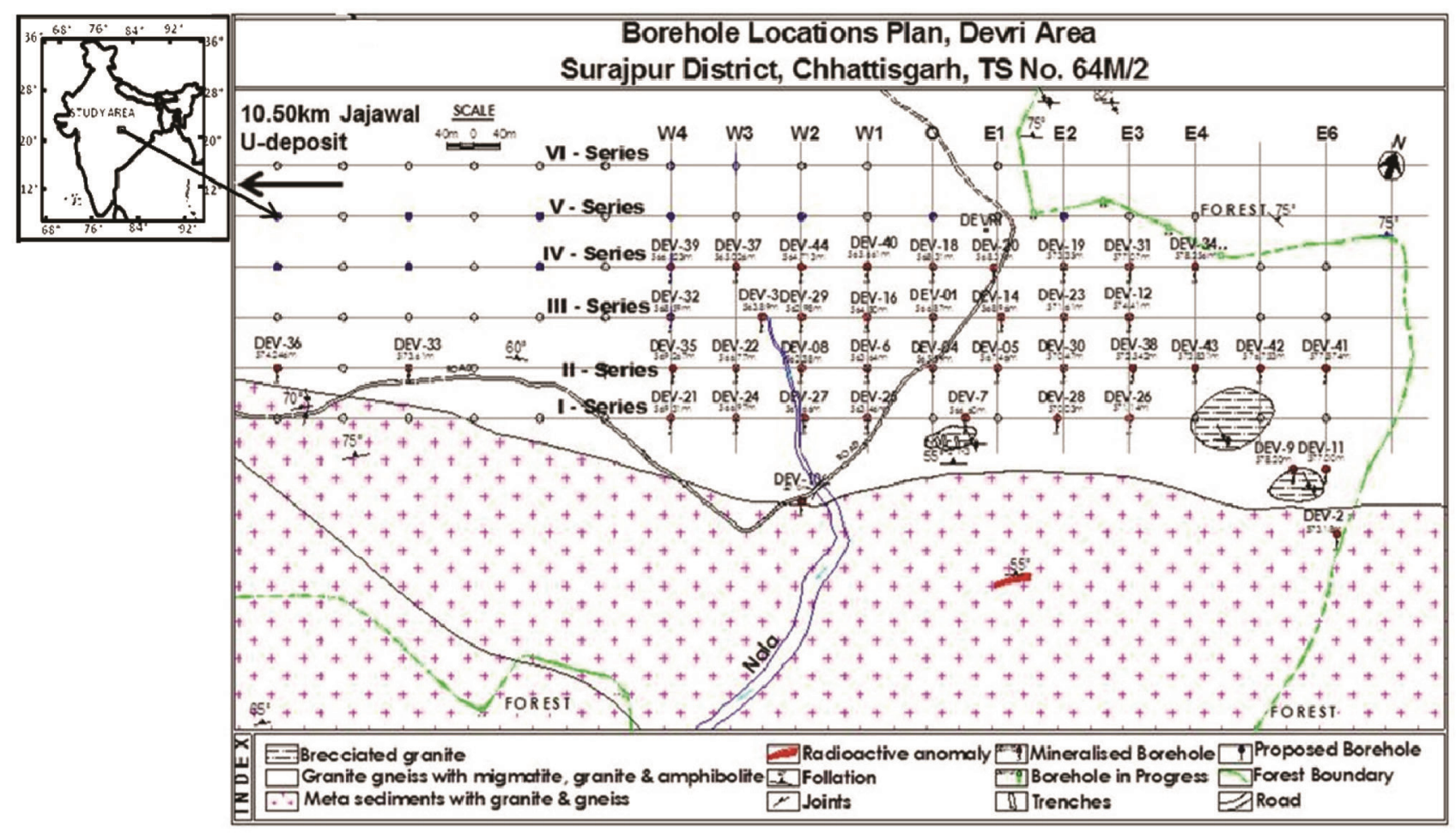

Figure 1. Geological map and borehole plan of Devri Area, Surajpur district, Chhattisgarh, India.

mainly associated with granite, granite mylonite, migmatite, granite-gneisses and pegmatite. Subsurface exploration in Devri area has revealed the presence of several uraniferous bands. Petrographically, radioactive core samples have been identified as granite cataclasite, sheared and brecciated granite, migmatite, gneisses and pegmatites. Radioactive phases identified are mainly uraninite, coffinite and brannerite, while at places uranium is adsorbed on hydrous iron oxide. Other associated ore minerals are pyrite, chalcopyrite, sphalerite, galena, ilemanite and rutile.

\section{Sampling and analysis}

In the process of uranium exploration, 43 boreholes were drilled and drill-core samples $(n=4470)$ were analysed. The samples were also subjected to disequilibrium study. Based on the borehole data, it was found that uranium mineralization exists up to $500 \mathrm{~m}$ depth beginning from a shallow depth of $7.10 \mathrm{~m}$. Interestingly, the grade of mineralization varied from $0.012 \%$ to $0.117 \% \mathrm{eU}_{3} \mathrm{O}_{8}$.

The drill core samples were crushed to -120 mesh to attain homogeneity and analysed using $\mathrm{NaI}(\mathrm{Tl})$-based gamma ray spectrometry and beta-gamma method to estimate their $\% \mathrm{U}_{3} \mathrm{O}_{8}, \%$ RaEq. $\left(\mathrm{U}_{3} \mathrm{O}_{8}\right), \% \mathrm{ThO}_{2}$ and $\% \mathrm{~K}$ content. The $\% \mathrm{U}_{3} \mathrm{O}_{8}$ content in the sample was estimated by beta-gamma method using pancake-type Geiger Muller tube and $1.75^{\prime \prime} \times 2^{\prime \prime} \mathrm{NaI}(\mathrm{Tl})$ scintillation detector. By simultaneous beta and gamma counting, it is possible to estimate the parent uranium concentration in the sample, irrespective of its state of equilibrium ${ }^{5}$.

The $\% \mathrm{U}_{3} \mathrm{O}_{8}$ estimation was carried out using the formula:

$$
\% \mathrm{U}_{3} \mathrm{O}_{8}=\mathrm{U}_{\beta}+C\left(\mathrm{U}_{\beta}-\mathrm{U}_{\gamma}\right)
$$

where $\mathrm{U}_{\beta}$ is the apparent uranium concentration due to beta activity, $\mathrm{U}_{\gamma}$ the apparent uranium concentration due to gamma activity and $C$ is the radium beta/uranium beta.

The beta-gamma technique was validated by analysing IAEA uranium reference standard RGU-1 $\left(\mathrm{U}_{3} \mathrm{O}_{8}=\right.$ $470 \mathrm{ppm})$. The $\mathrm{U}_{3} \mathrm{O}_{8}$ content of $\mathrm{RGU}-1$ estimated by this technique was $456 \mathrm{ppm} \pm 15 \mathrm{ppm}$.

Estimation of \% RaEq. $\left(\mathrm{U}_{3} \mathrm{O}_{8}\right)$ and $\% \mathrm{ThO}_{2}$ concentration in the sample was carried out using $5^{\prime \prime} \times 4^{\prime \prime} \mathrm{NaI}(\mathrm{Tl})$ based gamma ray spectrometry method ${ }^{6}$. For the estimation of RaEq. $\left(\mathrm{U}_{3} \mathrm{O}_{8}\right)$ and $\mathrm{ThO}_{2}$ contents in the sample, $1.76 \mathrm{MeV}$ of gamma-ray energy emitted by ${ }^{214} \mathrm{Bi}$, which is one of the daughters of the ${ }^{238} \mathrm{U}$ series, and $2.62 \mathrm{MeV}$ of gamma-ray energy emitted by ${ }^{208} \mathrm{Tl}$, which is one of the daughters of the ${ }^{232} \mathrm{Th}$ series, were used respectively. Energy calibration of gamma-ray spectrometry was done using mono-energetic gamma-ray sources ${ }^{137} \mathrm{Cs}$ and ${ }^{60} \mathrm{Co}$. The standards and samples were taken in the same polyethylene containers to nullify the geometry effects. The samples were kept on the detector and counting was done for sufficient time to minimize the error. To quantify the 
concentration of RaEq. $\left(\mathrm{U}_{3} \mathrm{O}_{8}\right)$ and $\mathrm{ThO}_{2}$ in the sample, the net peak areas of characteristic gamma-ray energies, i.e. 1.76 and $2.62 \mathrm{MeV}$ respectively, divided by their respective sensitivities ${ }^{7}$. The following formulae were used for the quantification of RaEq. $\left(\mathrm{U}_{3} \mathrm{O}_{8}\right)$ and $\mathrm{ThO}_{2}$ in the sample.

$$
\begin{aligned}
& \% \text { RaEq. }\left(\mathrm{U}_{3} \mathrm{O}_{8}\right)=\left[\left(N_{2}-\alpha N_{3}\right) /(1-a \alpha)\right] / S_{\mathrm{U}}, \\
& \% \mathrm{ThO}_{2}=\left[\left(N_{3}-a N_{2}\right) /(1-a \alpha)\right] / S_{\mathrm{Th}},
\end{aligned}
$$

where $N_{2}$ and $N_{3}$ are net counts in the uranium and thorium channel. $\alpha$ and $a$ are the stripping factors. $\alpha$ represents counts in uranium window per unit count in thorium window, and $a$ represents counts in thorium window per unit count in uranium window, $S_{\mathrm{U}}$ and $S_{\mathrm{Th}}$ are the sensitivities of uranium and thorium channel: $S_{\mathrm{U}}$ represents counts per second per unit concentration of uranium; $S_{\mathrm{Th}}$ represents counts per second per unit concentration of thorium.

$\mathrm{NaI}(\mathrm{Tl})$ detector-based gamma-ray spectrometry was validated by analysing IAEA uranium and thorium reference standard RGU-1 $\left(\mathrm{U}_{3} \mathrm{O}_{8}=470 \mathrm{ppm}\right)$ and RGTh-1 $\left(\mathrm{ThO}_{2}=910 \mathrm{ppm}\right)$. The RaEq. $\left(\mathrm{U}_{3} \mathrm{O}_{8}\right)$ content of RGU-1 estimated by this technique was $457 \pm 5 \mathrm{ppm}$, while $\mathrm{ThO}_{2}$ content was $895 \pm 12 \mathrm{ppm}$.

\section{Results and discussion}

Rosholt $^{8}$ had proposed the following general types of radioactive disequilibrium involving the uranium series: (i) Deficiency of daughter products where the relationship is $U>\mathrm{eRa}^{226}$. (ii) Time-related daughter product deficiency. (iii) Deficiency of $\mathrm{Th}^{230}$. (iv) Daughter product excess is represented by low uranium content. (v) Excess of $\mathrm{Ra}^{226}$ and its immediate daughter products. (vi) The occurrence of radium isotopes with very little or no $\mathrm{U}, \mathrm{Th}^{230}, \mathrm{~Pa}^{231}$ or $\mathrm{Th}^{232}$.

The type of disequilibrium condition shown by the samples from Devri area falls under type (i) of the classification of Rosholt detailed above ${ }^{2}$. It would indicate an excess of uranium as a result of recent deposition

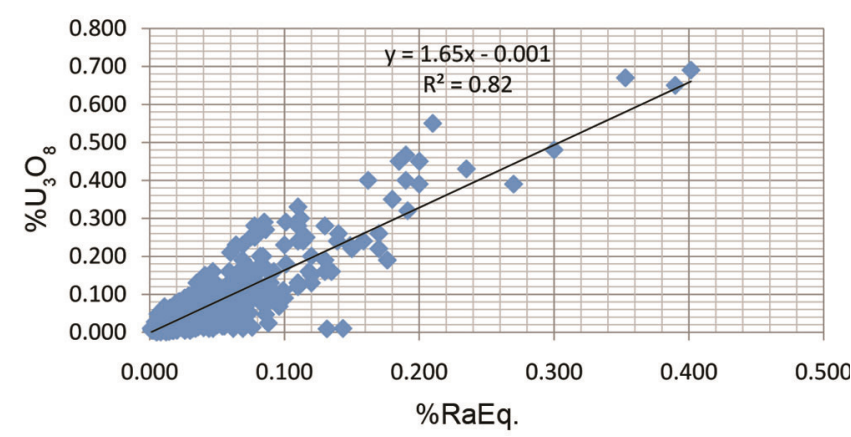

Figure 2. Linear regression plot between $\% \mathrm{Ra}\left(\mathrm{eU}_{3} \mathrm{O}_{8}\right)$ and $\% \mathrm{U}_{3} \mathrm{O}_{8}$ of borehole core samples $(n=4470)$. or deficiency of daughter products, mostly of radium group.

\section{Disequilibrium factor by regression analysis}

A regression line (Figure 2) was plotted between $\%$ RaEq. $\left(\mathrm{U}_{3} \mathrm{O}_{8}\right)$ and $\% \mathrm{U}_{3} \mathrm{O}_{8}$ contents of 4470 core samples of 43 boreholes (Figure 2) ${ }^{9}$ and the following regression equation was obtained $\% \mathrm{U}_{3} \mathrm{O}_{8}=1.65\left(\%\right.$ RaEq. $\left.\left(\mathrm{U}_{3} \mathrm{O}_{8}\right)\right)-$ 0.001 with $R^{2}=0.82$. This shows a disequilibrium factor of 1.65 .

A correlation coefficient of 0.82 was found, which shows significant enrichment of the parent uranium in Devri area. Disequilibrium factor was calculated for 4470 drill-core samples having $\mathrm{U}_{3} \mathrm{O}_{8}$ content $100 \mathrm{ppm}$ and above. A total of 205 samples had $\mathrm{U}_{3} \mathrm{O}_{8}$ content less than $100 \mathrm{ppm}$ and some of them were in favour of the daughters. These have not been considered for the calculation of disequilibrium factor (as samples having $\mathrm{U}_{3} \mathrm{O}_{8}$ content less than $100 \mathrm{ppm}$ cannot be estimated by the betagamma method). These represent only $4 \%-5 \%$ of total samples $(n=4470)$ and therefore do not have much significance.

\section{Disequilibrium factor by mean}

Disequilibrium factor of individual samples was calculated using the following formula

$$
\begin{aligned}
& \text { Disequilibrium factor }=\left\{\% \mathrm{U}_{3} \mathrm{O}_{8} / \% \mathrm{Ra}\left(\mathrm{eU}_{3} \mathrm{O}_{8}\right)\right\} \\
& \text { in a given sample. }
\end{aligned}
$$

Average disequilibrium factor of total 4470 samples of 43 boreholes was 1.65. Regression analysis of these samples gave the same disequilibrium factor (average disequilibrium factors of boreholes are given in Table 1 whose mean is also 1.60), which shows enrichment of uranium due to the cycle of dissolution, remobilization and deposition in Devri area. Leaching of daughter products and escape of radon, one of the gaseous members of the uranium series, further supports the enrichment of uranium. Most of the core samples of 43 boreholes also had significant $\mathrm{ThO}_{2}$ concentration, and average $\% \mathrm{ThO}_{2}$ concentration of the boreholes varied from $0.007 \%$ to $0.025 \%$ (Table 1). Uranium tonnage of Devri area thus should be estimated based on the results of the beta-gamma method, due to the presence of abundant $\mathrm{ThO}_{2}$ values instead of $\mathrm{eU}_{3} \mathrm{O}_{8}$ values obtained by gamma-ray logging of boreholes. Table 1 provides details of average of $\% \mathrm{U}_{3} \mathrm{O}_{8}, \% \mathrm{ThO}_{2}, \% \mathrm{Ra}\left(\mathrm{eU}_{3} \mathrm{O}_{8}\right)$ and disequilibrium factors of the 43 boreholes.

\section{Conclusion}

From the study of disequilibrium behaviour of uranium mineralization in Devri area, we can conclude the 
Table 1. Average $\% \mathrm{U}_{3} \mathrm{O}_{8}$, average $\% \mathrm{ThO}_{2}$, average $\% \mathrm{Ra}\left(\mathrm{eU}_{3} \mathrm{O}_{8}\right)$ and average disequilibrium factor of boreholes Devri area

\begin{tabular}{|c|c|c|c|c|c|}
\hline Borehole no. & $\begin{array}{l}\text { Total no. of } \\
\text { samples }\end{array}$ & $\begin{array}{l}\text { Average } \\
\% \mathrm{U}_{3} \mathrm{O}_{8}\end{array}$ & $\begin{array}{l}\text { Average } \\
\% \mathrm{ThO}_{2}\end{array}$ & $\begin{array}{c}\text { Average } \\
\% \mathrm{Ra}\left(\mathrm{eU}_{3} \mathrm{O}_{8}\right)\end{array}$ & $\begin{array}{c}\text { Average } \\
\text { disequilibrium factor }\end{array}$ \\
\hline $\mathrm{DEV} / 1$ & 94 & 0.072 & 0.004 & 0.041 & 1.64 \\
\hline $\mathrm{DEV} / 2$ & 23 & 0.017 & 0.017 & 0.009 & 1.97 \\
\hline $\mathrm{DEV} / 3$ & 41 & 0.018 & 0.007 & 0.014 & 1.53 \\
\hline $\mathrm{DEV} / 4$ & 185 & 0.026 & 0.009 & 0.016 & 1.67 \\
\hline $\mathrm{DEV} / 5$ & 200 & 0.029 & 0.006 & 0.018 & 1.65 \\
\hline $\mathrm{DEV} / 6$ & 143 & 0.029 & 0.007 & 0.022 & 1.52 \\
\hline $\mathrm{DEV} / 7$ & 115 & 0.037 & 0.009 & 0.024 & 1.65 \\
\hline $\mathrm{DEV} / 8$ & 76 & 0.012 & 0.014 & 0.009 & 1.57 \\
\hline $\mathrm{DEV} / 9$ & 88 & 0.014 & 0.016 & 0.009 & 1.65 \\
\hline $\mathrm{DEV} / 10$ & 39 & 0.014 & 0.023 & 0.008 & 1.95 \\
\hline $\mathrm{DEV} / 11$ & 72 & 0.018 & 0.019 & 0.011 & 1.68 \\
\hline $\mathrm{DEV} / 12$ & 110 & 0.027 & 0.008 & 0.018 & 1.58 \\
\hline $\mathrm{DEV} / 13$ & 34 & 0.022 & 0.010 & 0.017 & 1.39 \\
\hline $\mathrm{DEV} / 14$ & 115 & 0.030 & 0.016 & 0.019 & 1.58 \\
\hline $\mathrm{DEV} / 15$ & 22 & 0.014 & 0.016 & 0.009 & 1.69 \\
\hline $\mathrm{DEV} / 16$ & 145 & 0.022 & 0.014 & 0.015 & 1.53 \\
\hline $\mathrm{DEV} / 17$ & 13 & 0.012 & 0.025 & 0.008 & 1.59 \\
\hline $\mathrm{DEV} / 18$ & 215 & 0.021 & 0.012 & 0.014 & 1.58 \\
\hline $\mathrm{DEV} / 19$ & 146 & 0.024 & 0.012 & 0.015 & 1.54 \\
\hline $\mathrm{DEV} / 20$ & 132 & 0.042 & 0.014 & 0.025 & 1.62 \\
\hline $\mathrm{DEV} / 21$ & 46 & 0.028 & 0.011 & 0.016 & 1.59 \\
\hline $\mathrm{DEV} / 22$ & 86 & 0.035 & 0.017 & 0.025 & 1.66 \\
\hline $\mathrm{DEV} / 23$ & 103 & 0.020 & 0.014 & 0.012 & 1.62 \\
\hline $\mathrm{DEV} / 24$ & 81 & 0.021 & 0.019 & 0.013 & 1.93 \\
\hline $\mathrm{DEV} / 25$ & 88 & 0.023 & 0.019 & 0.012 & 1.90 \\
\hline $\mathrm{DEV} / 26$ & 83 & 0.015 & 0.016 & 0.009 & 1.77 \\
\hline $\mathrm{DEV} / 27$ & 140 & 0.017 & 0.020 & 0.009 & 1.89 \\
\hline $\mathrm{DEV} / 28$ & 75 & 0.026 & 0.020 & 0.014 & 1.84 \\
\hline $\mathrm{DEV} / 29$ & 89 & 0.021 & 0.011 & 0.014 & 1.56 \\
\hline $\mathrm{DEV} / 30$ & 102 & 0.020 & 0.011 & 0.014 & 1.56 \\
\hline $\mathrm{DEV} / 31$ & 104 & 0.019 & 0.010 & 0.013 & 1.51 \\
\hline $\mathrm{DEV} / 32$ & 89 & 0.020 & 0.011 & 0.013 & 1.61 \\
\hline $\mathrm{DEV} / 33$ & 212 & 0.022 & 0.012 & 0.014 & 1.65 \\
\hline $\mathrm{DEV} / 34$ & 257 & 0.029 & 0.011 & 0.020 & 1.54 \\
\hline $\mathrm{DEV} / 35$ & 79 & 0.020 & 0.015 & 0.012 & 1.85 \\
\hline $\mathrm{DEV} / 36$ & 134 & 0.025 & 0.010 & 0.014 & 1.84 \\
\hline $\mathrm{DEV} / 37$ & 67 & 0.017 & 0.011 & 0.013 & 1.54 \\
\hline $\mathrm{DEV} / 38$ & 86 & 0.026 & 0.014 & 0.014 & 1.70 \\
\hline $\mathrm{DEV} / 39$ & 106 & 0.022 & 0.011 & 0.014 & 1.57 \\
\hline $\mathrm{DEV} / 40$ & 45 & 0.025 & 0.007 & 0.016 & 1.59 \\
\hline $\mathrm{DEV} / 41$ & 144 & 0.019 & 0.011 & 0.012 & 1.69 \\
\hline $\mathrm{DEV} / 42$ & 121 & 0.034 & 0.013 & 0.019 & 1.79 \\
\hline $\mathrm{DEV} / 43$ & 125 & 0.024 & 0.011 & 0.016 & 1.57 \\
\hline
\end{tabular}

following: (a) Average disequilibrium factor is $1.65 \pm 0.01$, which indicates strong equilibrium in favour of the parent uranium. High amount of $\mathrm{ThO}_{2}$ is also present along with $\mathrm{U}_{3} \mathrm{O}_{8}$. (b) Therefore, while calculating total tonnage of uranium deposit in Devri area, we have to consider the average disequilibrium factor of 1.65 . This will further add to the total tonnage of uranium in the area.

1. Chimote, J. S., Singh, J. P. and Lall, Y., Studies on radioactive disequilibrium in the Bodal uranium ores by low energy gamma spectrometry. Indian J. Earth Sci., 1985, 12, 247-254.
2. Parthasarathy, T. N., Studies on the radioactive disequilibrium in the samples from Kulu and Rampur Himalayas, Himachal Pradesh. In Proceedings of the Symposium on Geology and Minerology of Atomic Mineral Deposits and their Development for use in the Nuclear Power Programme in India, 1968, vol. 37A.

3. Cumberland, S. A., Douglas, G., Grice, K. and Moreau, J. W., Uranium mobility inorganic matter-rich sediments: a review of geological and geochemical processes. Earth Sci. Rev., 2016, 159, $160-185$.

4. Rajeev, B., Sharma, U. P., Sinha, P. K., Majumdar, A. and Roy, M. K., A new sub-surface find of uranium mineralization in Devriarea, Proterozoic Surguja Crystalline Belt, Surguja district, Chhattisgarh. India. Curr. Sci., 2013, 104(2), 234-238.

5. Eichholz, G. G., Hilborn, J. W. and McMohan, C., The determination of uranium and thorium in ores. Can. J. Phys., 1953, 31, 613628. 


\section{RESEARCH ARTICLES}

6. Bhaumik, B. K., Bhattacharya, T., Acharyulu, A. A. P. S. R., Srinivas, D. and Shandilya, M. K., Principles of Radiometry in Radioactive Metal Exploration, First Edition Physics Lab., AMD, Eastern Region, Jamshedpur, India, 2004.

7. Grasty, R. L., Gamma ray spectrometric methods in uranium exploration - theory and operational procedures. In Geophysics and Geochemistry in the Search for Metallic Ores, Geological Survey of Canada, Economic Geology Report No. 31, 1979, pp. $147-161$.

8. Rosholt, J. N., Natural radioactive disequilibrium of the uranium series. US Geological Surv., Bull. 1084-A, 1953.

9. Shrivastava, H. B. et al., Uranium series disequilibrium studies in Chenchu colony area, Guntur district, Andhra Pradesh, India. Appl. Rad. Isot., 2015, 105, 163-169.
ACKNOWLEDGEMENTS. We thank the Director, Atomic Minerals Directorate for Exploration and Research (AMD), Department of Atomic Energy, for permission to publish this article, and the Additional Director (OP-II) and Additional Director (R\&D) for encouragement, useful suggestions and guidance during the study. We also thank the staff of Sarguja Investigation, AMD/CR, Nagpur for their valuable suggestions, and staff of the Physics Laboratory, AMD/CR, for technical discussions and support.

Received 15 May 2020; revised accepted 25 March 2021

doi: $10.18520 / \mathrm{cs} / \mathrm{v} 120 / \mathrm{i} 11 / 1753-1757$ 